\section{CPPU Influences Fruit Quality and Fruit Abscission of 'McIntosh' Apples}

\author{
Duane W. Greene \\ Department of Plant and Soil Sciences, University of Massachusetts, Amherst, \\ MA 01003
}

Additional index words. cytokinin, fruit thinning, flowering, diphenylureas,

Malus $\times$ domestica, postharvest storage, flowering

\begin{abstract}
A range of concentrations and timings of CPPU application were evaluated in attempt to identify situations in which fruit size, flesh firmness, and soluble solids could be increased while minimizing increased incidence of fruit asymmetry and reductions in flower bud formation and fruit surface red color on 'McIntosh' apples (Malus $\times$ domestica Borkh.). The greatest response to CPPU for most attributes evaluated occurred when it was applied at fruit size between $6 \mathrm{~mm}$ and $16 \mathrm{~mm}$. The conclusion from this series of experiments is that differential response to CPPU could not be established by altering the time of application. The response to CPPU is linear with increasing concentration. Results suggested that use of 4 to $6 \mathrm{mg} \cdot \mathrm{L}^{-1} \mathrm{CPPU}$ on apples to increase fruit size was the maximum and appropriate range to use without causing fruit asymmetry. Chemical name used: $N$-(2-chloro-4-pyridyl)- $N^{\prime}$-phenyl urea (CPPU)
\end{abstract}

Fruit size is a dominant factor determining the return a grower receives for apples (Looney, 1993). Commercially, fruit size is increased primarily by crop load reduction with chemical thinners. Although the total yield is reduced by thinning, the remaining fruit have higher value because of increased fruit size (Forshey, 1986). The cytokinin benzyladenine (BA) is the active ingredient in the commercial thinner Accel $^{\circledR}$ that increases fruit size conventionally by thinning, but it also increases fruit size independently of this event by stimulating additional cell division within the fruit (Greene, 1993b, Wismer et al., 1995). CPPU and thidiazuron are diphenylurea compounds that have strong cytokinin activity. Both appear to respond by increasing fruit size through crop load reduction and increased cell division in a manner similar to BA (Elfving and Cline, 1993, Greene, 1995).

There are several reports on the use of CPPU and thidiazuron on apples (Bangerth and Schroeder, 1994; Curry and Greene, 1993; Elfving and Cline, 1993; Greene, 1989; Greene, 1993a, 1995, 1996; Sugiyama et al., 1993; Tartarini et al., 1993). In most of these studies, the rates used exceed $10 \mathrm{mg} \cdot \mathrm{L}^{-1}$, and while the responses on fruit size were generally large and impressive, there were undesirable side effects such as asymmetrical fruit and reduced red color and return bloom. Greene (1995) previously reported on the effects of lower rates of thidiazuron on apples. This study was undertaken to determine if CPPU concentration or time of application could be adjusted to preserve the positive effects on fruit, while minimizing undesirable side effects.

Received for publication 31 Aug. 2000. Accepted for publication 11 Apr. 2001. This material is based upon work supported by the Cooperative State Research, Extension, Education Service, U.S. Dept. of Agriculture, Massachusetts Agricultural Experiment Station, as Journal paper 3276, Under Project No. 747.

\section{Materials and Methods}

Plant material. All trees used in this investigation were growing at the Univ. of Massachusetts Horticultural Research Center in Belchertown. Normal cultural and pest control practices were used.

Timing Expt. 1. Two limbs, 10 to $12 \mathrm{~cm}$ in circumference, on each of 96 'Marshall McIntosh'/M.9 trees were selected and tagged. Just prior to the pink stage of flower development, all blossom clusters were counted on the tagged limbs and then blossom cluster density was calculated. Trees were grouped into 12 blocks (replications) of 8 trees each, based on tree size, bloom density, and location within the block. Beginning on 26 Apr. 1991 at the pink stage of flower development, one tree in each block received a dilute spray of $8 \mathrm{mg} \cdot \mathrm{L}^{-1}$ CPPU containing $0.025 \%$ Buffer-X (Kalo, Overland Park, Kans.) applied with a handgun sprayer to runoff. One additional tree in each block received the same CPPU spray on either $3,9,15,20,28$, or 31 May, which phenologically correspond to full bloom, petal fall, and average fruit sizes of $5.6 \mathrm{~mm}, 10.1 \mathrm{~mm}, 16.1$ $\mathrm{mm}$, and $21.9 \mathrm{~mm}$, respectively. One tree in each block was left unsprayed and served as the control. At the completion of June drop in early July all persisting fruit on tagged limbs were counted.

At the time of commercial harvest on 5 Sept., a 30-apple sample was randomly harvested from each tree. All fruit were weighed and then red color was visually estimated on each fruit to the nearest $10 \%$ and the intensity of red color was noted to determine if each met U.S. Extra Fancy standards for red color intensity. Fruit were also rated and designated as having either normal or irregular shape. Ten representative fruit were selected from each sample and the flesh firmness was determined with two punctures using an Effegi penetrometer (McCormick Fruit Tech, Yakima, Wash.) equipped with an 11-mm head. Soluble solids concentration (SSC) was determined with a hand refractometer Fisher Scientific, Pittsburgh) from a composite sample of the juice collected during the flesh firmness test. A 1$\mathrm{cm}$ slice was taken at the equator of each fruit used for the firmness test. From each one of these slices a 1-cm tissue disk was removed with a cork borer from four quadrants of the slice. A composite sample of 40 tissue disks from the 10 apples was frozen at $-20{ }^{\circ} \mathrm{C}$. Calcium concentration in the samples was later determined using the method of Weis et al. (1985). All viable seeds were counted in the ten fruit used for flesh firmness determination and an additional ten fruit randomly selected from the remaining 20 fruit. A separate $10-\mathrm{kg}$ sample was harvested from each tree and placed in regular air storage at $0{ }^{\circ} \mathrm{C}$. Fruit were removed after 20 weeks in storage and flesh firmness was determined on a 10-apple sample, similar to that described at harvest. The remaining fruit were left at $20{ }^{\circ} \mathrm{C}$ for $12 \mathrm{~d}$ and then storage disorders were assessed. Return bloom was determined at the pink stage on two 10 to $12 \mathrm{~cm}$ circumference limbs per tree the following spring.

Timing and concentration Expt. 2. Two limbs 10 to $15 \mathrm{~cm}$ in circumference on each of 40 mature 'Rogers McIntosh'/M.7 trees were selected, tagged, and the circumference measured. At the pink stage of flower development, all blossom clusters were counted on the tagged limbs and then blossom cluster density was calculated. Trees were grouped into 8 blocks (replications) of 5 trees each, based on tree size, bloom density, and location in the block. One tree in each replication was sprayed to the drip point with a solution containing $1,2,4$, or $8 \mathrm{mg} \cdot \mathrm{L}^{-1} \mathrm{CPPU}$ in $0.025 \%$ Buffer-X on 16 May when fruit size averaged $7.3 \mathrm{~mm}$. The remaining tree in each replication was not sprayed and served as the control. Fruit were harvested at the appropriate time for commercial harvest on 10 Sept. Harvest and fruit evaluation were similar to that described in Expt. 1 with the following exceptions. Fruit asymmetry was assessed first as fruit with any appearance of asymmetric shape. Fruit were again graded to evaluate if the irregular shape was great enough so that it would not meet the U.S. Extra Fancy grade. A $20-\mathrm{kg}$ fruit sample was taken from each tree for evaluation of storage potential in regular air storage.

Concentration and time of application Expt. 3. A block containing 64 mature 'McIntosh'/M.7 trees was selected. Limb selection, bloom determination and blocking into appropriate replications was similar to that described in Expt. 2. Trees were grouped into 8 blocks (replications) of 8 trees each. Three trees in each replication were sprayed to the drip point with either 2,4 , or $6 \mathrm{mg} \cdot \mathrm{L}^{-1}$ CPPU containing $0.25 \%$ Regulaid (Kalo, Overland Park, Kans.) at petal fall on 22 May, and three different trees were sprayed with the same CPPU treatments on 26 May, when fruit size averaged 5 to $6 \mathrm{~mm}$ in diameter. The two remaining trees in each block were unsprayed and served as controls for the two times of application. A 30-apple sample was randomly 
Table 1. Effect of timing of $8 \mathrm{mg} \cdot \mathrm{L}^{-1}$ CPPU application on fruit set, fruit characteristics, and return bloom of 'Marshall McIntosh'/M.9, 1991.

\begin{tabular}{|c|c|c|c|c|c|c|c|c|c|c|c|}
\hline \multicolumn{2}{|c|}{ Treatment } & \multicolumn{2}{|c|}{ Fruit per } & \multirow{2}{*}{$\begin{array}{c}\text { Blossom cluster } \\
\text { per } \mathrm{cm}^{2} \text { limb } \\
\text { X-section area }\end{array}$} & \multirow{2}{*}{$\begin{array}{l}\text { Fruit } \\
\text { wt } \\
(\mathrm{g})\end{array}$} & \multirow{2}{*}{$\begin{array}{c}\text { Flesh } \\
\text { firmness } \\
(\mathrm{N})\end{array}$} & \multirow{2}{*}{$\begin{array}{l}\text { Soluble } \\
\text { solids } \\
(\%)\end{array}$} & \multirow{2}{*}{$\begin{array}{c}\text { Red } \\
\text { color } \\
(\%)\end{array}$} & \multirow{2}{*}{$\begin{array}{c}\text { U.S. Extra } \\
\text { Fancy } \\
(\%)\end{array}$} & \multirow{2}{*}{$\begin{array}{c}\text { Asymmetrical } \\
\text { fruit } \\
(\%)\end{array}$} & \multirow{2}{*}{$\begin{array}{c}\text { Seeds } \\
\text { per } \\
\text { fruit }\end{array}$} \\
\hline $\begin{array}{l}\text { Date of } \\
\text { application }\end{array}$ & $\begin{array}{l}\text { Flower or } \\
\text { fruit stage }\end{array}$ & $\begin{array}{c}\mathrm{cm}^{2} \operatorname{limb} \\
\mathrm{x} \text {-section area }\end{array}$ & $\begin{array}{l}100 \text { blossom } \\
\text { clusters }\end{array}$ & & & & & & & & \\
\hline & & -----199 & $1----$ & 1992 & & & & & & & \\
\hline Control & --- & $7.9^{\mathrm{z}}$ & 37 & 13.3 & 150 & 71.5 & 11.5 & 72 & 77 & 7.2 & 6.0 \\
\hline 26 April & Pink & 7.4 & 32 & 14.3 & 156 & 70.6 & 11.5 & 73 & 72 & 26.9 & 5.7 \\
\hline 3 May & Full bloom & 8.6 & 38 & 13.0 & 159 & 70.2 & 11.2 & 72 & 71 & 27.8 & 5.6 \\
\hline 9 May & Petal fall & 6.9 & 35 & 13.4 & 175 & 70.2 & 11.2 & 72 & 67 & 43.9 & 5.1 \\
\hline 15 May & $5.6 \mathrm{~mm}$ & 4.7 & 22 & 17.1 & 177 & 74.3 & 12.0 & 65 & 55 & 51.7 & 4.4 \\
\hline 20 May & $10.1 \mathrm{~mm}$ & 5.1 & 26 & 15.5 & 180 & 72.9 & 11.9 & 66 & 58 & 78.2 & 2.8 \\
\hline 28 May & $16.1 \mathrm{~mm}$ & 10.1 & 45 & 9.1 & 154 & 69.7 & 11.3 & 68 & 61 & 54.2 & 3.1 \\
\hline 31 May & $21.9 \mathrm{~mm}$ & 8.0 & 36 & 10.6 & 161 & 69.2 & 11.2 & 71 & 72 & 33.1 & 5.5 \\
\hline Significance & & $\mathrm{Q}^{* * * *}$ & $\mathrm{Q}^{* * *}$ & $\mathrm{~L}^{* *} \mathrm{Q}^{* *}$ & $\mathrm{Q}^{* * * *}$ & $\mathrm{Q}^{* *}$ & $\mathrm{Q}^{* * *} \mathrm{C}^{* * * *}$ & $\mathrm{~L}^{* *} \mathrm{Q}^{* * *}$ & $\mathrm{Q}^{*}$ & $\mathrm{~L}^{* * * *} \mathrm{Q}^{* * *} \mathrm{C}^{*} \mathrm{~L}$ & ${ }^{* * * *} \mathrm{Q}^{* * *} \mathrm{C}^{*}$ \\
\hline Control vs. CPPU & & NS & NS & NS & $* * *$ & NS & NS & $*$ & $*$ & $* * *$ & *** \\
\hline
\end{tabular}

harvested from each tree on 23 Sept. and evaluated as previously described in Expt. 2 with one exception; ten fruit from the 30-apple sample were cut in half, dipped in an iodine solution, and the blue/black color was rated to give an indication of starch content and the stage of fruit ripeness (Priest and Lougheed, 1981). A 20-kg fruit sample was harvested from the periphery of each tree on 24 Sept. and placed in regular air storage at $0{ }^{\circ} \mathrm{C}$ and was evaluated for postharvest potential as previously described.

Statistical analysis. Analysis of variance was used with both experiments to determine significance of treatments. Where appropriate, means were separated by orthogonal polynomial comparison or analysis of regression.

\section{Results}

Concentration Expt 1. CPPU caused fruit thinning only when applied at 5 and $10 \mathrm{~mm}$ of fruit size, the stage of development when apples are generally most susceptible to a chemical thinning spray (Table 1). CPPU increased return bloom on trees that it thinned the previous year, but it may have decreased bloom when applied when fruit size ranged between 16 and $22 \mathrm{~mm}$. CPPU significantly increased fruit size but the maximum response was noticed when it was applied between petal fall and $10 \mathrm{~mm}$. CPPU affected flesh firmness and SSC quadratically and appeared to increase these when applied between 6- and 10-mm fruit size. Fruit surface red color and the percentage of fruit classified as U.S. Extra Fancy were reduced when sprays were applied between 6 and $16 \mathrm{~mm}$. Fruit asymmetry was increased and seed number

Table 2. Effect of $8 \mathrm{mg} \cdot \mathrm{L}^{-1}$ CPPU applied over time to 'Marshall McIntosh'/M.9 on flesh firmness, fruit calcium content, and development of storage disorders following air storage at $0{ }^{\circ} \mathrm{C}$ for 20 weeks.

\begin{tabular}{lccccc}
\hline $\begin{array}{l}\text { Treatment } \\
\text { flower or fruit stage }\end{array}$ & $\begin{array}{c}\text { Flesh firmness } \\
(\mathrm{N})\end{array}$ & $\begin{array}{c}\text { Senescent breakdown } \\
(\%)\end{array}$ & $\begin{array}{c}\text { Decay } \\
(\%)\end{array}$ & $\begin{array}{c}\text { Scald } \\
(\%)\end{array}$ & $\begin{array}{c}\text { Fruit calcium } \\
\left(\mathrm{mg} \cdot \mathrm{L}^{-1}\right)\end{array}$ \\
\hline Control & 36.7 & 19 & 20 & 33 & 212 \\
Pink & 36.2 & 11 & 23 & 28 & 196 \\
Full bloom & 36.2 & 21 & 16 & 27 & 210 \\
Petal fall & 36.2 & 21 & 18 & 40 & 192 \\
FB + 5.6 mm & 37.6 & 21 & 20 & 48 & 179 \\
FB + 10.1 mm & 37.2 & 39 & 30 & 53 & 180 \\
FB + 16.1 mm & 34.4 & 21 & 30 & 45 & 190 \\
FB + 21.9 mm & 33.9 & 14 & 21 & 50 & 219 \\
Significance & $\mathrm{L}^{* *} \mathrm{Q}^{* * *}$ & $\mathrm{Q}^{* *}$ & $\mathrm{~L}^{*}$ & $\mathrm{~L}^{* * *}$ & $\mathrm{Q}^{* *} \mathrm{C}^{*}$ \\
\hline
\end{tabular}

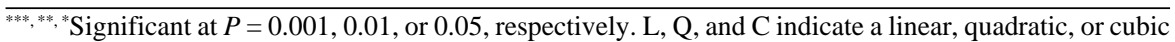
response, respectively.

was decreased by all CPPU treatments but the greatest response was when it was applied when fruit size was between 6 and $16 \mathrm{~mm}$. Following regular air storage for 20 weeks at $0{ }^{\circ} \mathrm{C}$, CPPU decreased flesh firmness, increased senescent breakdown, increased scald, and decreased fruit flesh calcium (Table 2). In general, the responses were greatest for all parameters when CPPU was applied when fruit size was between 6 and $16 \mathrm{~mm}$.

Concentration Expt. 2. As the concentration of CPPU increased there was a linear reduction in fruit set and seed number, but a linear increase in fruit weight, fruit flesh firmness, SSC, and the percentage of asymmetrical fruit (Table 3). However, no treatment influenced return bloom, fruit red color, or the percentage of fruit graded into the U.S. Extra Fancy category. Flesh firmness and fruit flesh calcium of fruit following 20 weeks of regular air storage was not affected by treatment (Table 4). Senescent breakdown and scald increased linearly with increasing concentration of CPPU.
Time and concentration Expt. 3. As the concentration of CPPU increased there was a linear reduction in fruit set and seed number, and a delay in ripening as determined by starch degradation pattern (Table 5). CPPU caused a linear increase in fruit weight, fruit flesh calcium, SSC, asymmetric fruit, and asymmetric fruit that lowered U.S. Grade as the concentration of CPPU increased. The time of application did not influence the response to CPPU. Return bloom, fruit red color, and the percentage of fruit graded into the U.S. Extra Fancy grade were not affected by treatment (data not shown). CPPU increased scald linearly following storage from $1 \%$ for untreated fruit to slightly $<6 \%$ for fruit receiving $6 \mathrm{mg} \cdot \mathrm{L}^{-1}$ (data not shown). There were no other treatment effects on fruit evaluated following storage.

\section{Discussion}

One of the goals of this investigation was to establish the influence that the time of applica-

Table 3. Effect of CPPU concentration applied at 5-6 mm on fruit set, return bloom, and fruit quality of 'McIntosh'/M.7, 1991.

\begin{tabular}{|c|c|c|c|c|c|c|c|c|c|c|c|}
\hline \multirow{2}{*}{$\begin{array}{l}\text { CPPU } \\
\text { concentration } \\
\left(\mathrm{mg} \cdot \mathrm{L}^{-1}\right)\end{array}$} & \multicolumn{2}{|c|}{ Fruit per } & \multirow{2}{*}{$\begin{array}{c}\text { Blossom cluster } \\
\text { per } \mathrm{cm}^{2} \text { limb } \\
\mathrm{x} \text {-section area }\end{array}$} & \multirow{2}{*}{$\begin{array}{c}\text { Fruit } \\
\text { wt } \\
(\mathrm{g}) \\
\end{array}$} & \multirow{2}{*}{$\begin{array}{c}\text { Flesh } \\
\text { firmness } \\
(\mathrm{N})\end{array}$} & \multirow{2}{*}{$\begin{array}{c}\text { Soluble } \\
\text { solids } \\
(\%) \\
\end{array}$} & \multirow{2}{*}{$\begin{array}{c}\text { Red } \\
\text { color } \\
(\%) \\
\end{array}$} & \multirow{2}{*}{$\begin{array}{l}\text { U.S. Extra } \\
\text { Fancy } \\
(\%)\end{array}$} & \multirow{2}{*}{$\begin{array}{l}\text { Asymmetrical } \\
\text { fruit } \\
(\%)\end{array}$} & \multirow{2}{*}{$\begin{array}{c}\text { Asymmetrical } \\
\text { fruit unacceptable } \\
(\%)\end{array}$} & \multirow{2}{*}{$\begin{array}{c}\text { Seeds } \\
\text { per } \\
\text { fruit } \\
\end{array}$} \\
\hline & $\begin{array}{c}\mathrm{cm}^{2} \text { limb } \\
\mathrm{x} \text {-section area }\end{array}$ & $\begin{array}{l}100 \text { blossom } \\
\text { clusters }\end{array}$ & & & & & & & & & \\
\hline & ----1991 & $1----$ & 1992 & & & & & & & & \\
\hline 1 & 5.9 & 43 & 14.1 & 146 & 70.6 & 10.8 & 58 & 22.1 & 10.5 & 2.9 & 6.0 \\
\hline 2 & 5.7 & 41 & 12.2 & 156 & 71.1 & 11.1 & 57 & 13.5 & 24.7 & 5.4 & 6.2 \\
\hline 4 & 4.9 & 27 & 13.6 & 157 & 73.4 & 11.2 & 57 & 20.4 & 36.9 & 9.1 & 4.9 \\
\hline 8 & 4.3 & 32 & 11.3 & 168 & 73.8 & 11.3 & 59 & 16.7 & 64.1 & 30.3 & 4.3 \\
\hline
\end{tabular}

$\overline{\mathrm{Ns},{ }^{* * *}, * *, *}$ Nonsignificant or significant at $P=0.001,0.01$, or 0.05 , respectively. L indicates a linear response. 
Table 4. Effect of CPPU concentration applied at 5-6 $\mathrm{mm}$ to 'McIntosh'/M.7 on flesh firmness, fruit calcium content, and development of storage disorders following air storage for 20 weeks.

\begin{tabular}{lccccc}
\hline $\begin{array}{l}\text { CPPU concentration } \\
\left(\mathrm{mg} \cdot \mathrm{L}^{-1}\right)\end{array}$ & $\begin{array}{c}\text { Flesh firmness } \\
(\mathrm{N})\end{array}$ & $\begin{array}{c}\text { Senescent breakdown } \\
(\%)\end{array}$ & $\begin{array}{c}\text { Decay } \\
(\%)\end{array}$ & $\begin{array}{c}\text { Scald } \\
(\%)\end{array}$ & $\begin{array}{c}\text { Fruit calcium } \\
\left(\mathrm{mg} \cdot \mathrm{L}^{-1}\right)\end{array}$ \\
\hline 0 & 33.9 & 9 & 30 & 8 & 199 \\
1 & 33.9 & 10 & 34 & 8 & 210 \\
2 & 34.4 & 13 & 31 & 10 & 195 \\
4 & 34.4 & 14 & 34 & 13 & 205 \\
8 & 34.4 & 19 & 32 & 21 & 182 \\
Significance & $\mathrm{NS}$ & $\mathrm{L}^{* * *}$ & $\mathrm{NS}$ & $\mathrm{L}^{* * * *}$ & $\mathrm{NS}$ \\
\hline Ns, **** Nonsignificant or significant at $P=0.001$, respectively. L indicates a linear response.
\end{tabular}

Ns, ${ }^{* * *}$ Nonsignificant or significant at $P=0.001$, respectively. L indicates a linear response.

tion had on the many responses to CPPU. Treatments were applied over a 35-d period starting at pink and extending through the most rapid period of cell division to $\approx 22 \mathrm{~mm}$ average fruit size, a time when fruit are rarely influenced by hormone-type thinners. There was a minimal response to treatment applied at full bloom or earlier. Clearly, the most responsive developmental stage to CPPU application coincides with the time that fruitlets are the most susceptible to other chemical thinners, the $6 \mathrm{~mm}$ to $10 \mathrm{~mm}$ stage in this investigation. The maximum increase in fruit weight, flesh firmness, and SSC, all positive responses, occurred in this time period. However, the reduction in surface red color and seed number per fruit, and a large increase in fruit asymmetry, which can exclude fruit from the U.S. Extra Fancy grade, also peaked during this time period. Therefore, it appears that adjustment of the time of application of CPPU may not be a viable approach to emphasizing positive responses while minimizing negative side effects.

Several studies have reported that CPPU and the related diphenylurea, thidiazuron, inhibit flower bud formation (Curry and Greene, 1993; Greene, 1989, 1996). In all of these cases the concentration used was considerably higher than those used in this study. CPPU did not inhibit flower bud formation in this study, and in Expt. 1 where modest thinning was noted, there was an increase in return bloom. Therefore, inhibition of flowering should not be considered a factor when using CPPU at the concentrations reported in this investigation.

The responses to CPPU concentration are in general linear (Greene, 1989, 1996). Therefore, selection of an appropriate concentration to use on apples by statistical means may not be meaningful. The concentrations used in this investigation ranged between 1 and 8 $\mathrm{mg} \cdot \mathrm{L}^{-1}$. Fruit asymmetry caused by $8 \mathrm{mg} \cdot \mathrm{L}^{-1}$ occurred on over $60 \%$ of the fruit while fruit weight, flesh firmness, and soluble solids increases following application of 1 or 2 $\mathrm{mg} \cdot \mathrm{L}^{-1}$ were minimal at best. Unless other strategies can be worked out to reduce fruit asymmetry caused by higher rates, concentrations of CPPU between 4 and $6 \mathrm{mg} \cdot \mathrm{L}^{-1}$ maybe best for use on apples although even these rates can result in a substantial percentage of asymmetric fruit. Earlier reports (Greene, 1989, 1996) suggested that the thinning caused by CPPU was a negative response since it was also associated with reduced flower bud formation. In these earlier studies concentrations of $10 \mathrm{mg} \cdot \mathrm{L}^{-1}$ or greater were used. In this investigation concentrations between 1 and 8 $\mathrm{mg} \cdot \mathrm{L}^{-1}$ were used, mild to moderate thinning was observed at some timings in all experiments, and there was only a modest reduction in flowering at late timings with $8 \mathrm{mg} \cdot \mathrm{L}^{-1}$. Bukovac et al. (1998) reported that CPPU at 5 $\mathrm{mg} \cdot \mathrm{L}^{-1}$ combined with NAA at $15 \mathrm{mg} \cdot \mathrm{L}^{-1}$ was an effective thinning combination for use on 'Delicious', primarily due to enhanced fruit size.

Greene (1996) previously reported that CPPU increased senescent breakdown of 'McIntosh' apples following storage and this was confirmed in 2 of the 3 experiments reported here. CPPU frequently reduces seed number and Bramlage et al. (1990) have shown a direct relationship between seed number and flesh $\mathrm{Ca}$. Seed number was reduced in all 3 experiments, senescent breakdown was increased in 2 experiments, and fruit $\mathrm{Ca}$ was reduced in only one experiment. Therefore, increased senescent breakdown can not be attributed solely to reduced calcium through a reduction in seed number. Alternatively, fruit $\mathrm{Ca}$ is decreased by dilution as fruit size increases, and this may be a contributing factor to increased senescent breakdown.

CPPU and thidiazuron are structurally very similar, and several investigations have concluded that responses to these two compounds were very similar when tested on apples in the same experiment (Curry and Greene, 1993; Greene, 1993a, 1995). Therefore, it seems reasonable that the conclusions reached in this investigation using CPPU may provide insight to responses to thidiazuron.

Fruit asymmetry is clearly one of the obstacles that may prevent commercial use of CPPU on apples. It is well documented that CPPU is a very strong promoter of cell division (Fellman et al., 1987; Mok et al., 1987). Application of CPPU in most reports in the literature has been by dilute application or dipping which will result in asymmetric distribution on the developing fruit. CPPU is highly immobile (Basi et al., 1993) so increases in cell division on fruit are restricted to the immediate areas where the droplet is applied. Application techniques that bring about uniform distribution of the spray droplets may result in a considerable reduction in the incidence of asymmetric fruit. The use of silicone based surfactants and spray application techniques that produce smaller particle sizes may be two such strategies to achieve uniform spray distribution and reduced asymmetry following CPPU application.

\section{Literature Cited}

Bangerth, F. and M. Schroeder. 1994. Strong synergistic effects of gibberellins with the synthetic cytokinin $N$-(2-chloro-4-pyridyl)- $N$-phenylurea on parthenocarpic fruit set and some other fruit characteristics of apple. Plant Growth Regulat. 15:293-302.

Basi, R., D. Neri, N. Sugiyama, and G. Costa. 1993. ${ }^{14} \mathrm{C}$-CPPU uptake and distribution in developing kiwifruits and apples. Acta Hort. 329:101-104.

Bramlage, W.J., S.A. Weis, and D.W. Greene. 1990. Observations on the relationship among seed number, fruit calcium, and senescent breakdown in apples. HortScience 25:351-353.

Table 5. Effect of time of application and concentration of CPPU on fruit set, fruit characteristics, and return bloom of 'McIntosh'/M.7, 1992.

\begin{tabular}{|c|c|c|c|c|c|c|c|c|c|c|c|}
\hline \multirow{2}{*}{$\begin{array}{l}\text { Treatment } \\
\text { CPPU concentration } \\
\left(\mathrm{mg} \cdot \mathrm{L}^{-1}\right)\end{array}$} & \multirow[b]{2}{*}{ Stage } & \multicolumn{2}{|c|}{ Fruit per } & \multirow{2}{*}{$\begin{array}{l}\text { Blossom cluster } \\
\text { per } \mathrm{cm}^{2} \text { limb } \\
\text { X-section area }\end{array}$} & \multirow{2}{*}{$\begin{array}{c}\text { Fruit } \\
\text { wt } \\
\text { (g) }\end{array}$} & \multirow{2}{*}{$\begin{array}{c}\text { Flesh } \\
\text { firmness } \\
(\mathrm{N})\end{array}$} & \multirow{2}{*}{$\begin{array}{l}\text { Soluble } \\
\text { solids } \\
(\%)\end{array}$} & \multirow[b]{2}{*}{$\begin{array}{l}\text { Starch } \\
\text { rating }\end{array}$} & \multirow[b]{2}{*}{$\begin{array}{c}\text { Seed } \\
\text { number }\end{array}$} & \multirow{2}{*}{$\begin{array}{c}\text { Asymmetric } \\
\text { fruit } \\
(\%)\end{array}$} & \multirow{2}{*}{$\begin{array}{l}\text { Asymmetrical } \\
\text { fruit that lower } \\
\text { grade }(\%)\end{array}$} \\
\hline & & $\begin{array}{c}\mathrm{cm}^{2} \operatorname{limb} \\
\mathrm{x}-\text { section area }\end{array}$ & $\begin{array}{c}100 \text { blossom } \\
\text { clusters }\end{array}$ & & & & & & & & \\
\hline & & -----199 & $2----$ & 1993 & & & & & & & \\
\hline 0 & Petal fall & 5.3 & 45 & 10.8 & 162 & 69.7 & 11.3 & 4.6 & 9.1 & 3.8 & 0.7 \\
\hline 2 & Petal fall & 4.2 & 30 & 10.2 & 170 & 71.1 & 11.6 & 4.3 & 8.2 & 9.5 & 2.4 \\
\hline 4 & Petal fall & 2.9 & 22 & 7.2 & 179 & 72.5 & 11.6 & 4.1 & 7.1 & 25.9 & 7.4 \\
\hline 6 & Petal fall & 2.7 & 27 & 13.6 & 187 & 76.1 & 11.9 & 4.2 & 5.7 & 48.8 & 21.2 \\
\hline 0 & $5-6 \mathrm{~mm}$ & 5.0 & 36 & 11.1 & 160 & 69.7 & 11.5 & 4.7 & 9.3 & 2.9 & 0.8 \\
\hline 2 & $5-6 \mathrm{~mm}$ & 3.0 & 25 & 11.2 & 169 & 71.1 & 11.6 & 4.4 & 8.0 & 7.1 & 3.7 \\
\hline 4 & $5-6 \mathrm{~mm}$ & 2.7 & 23 & 6.9 & 180 & 72.0 & 11.6 & 4.5 & 6.3 & 24.5 & 13.0 \\
\hline 6 & $5-6 \mathrm{~mm}$ & 2.3 & 21 & 9.5 & 183 & 76.1 & 12.0 & 4.4 & 4.0 & 52.5 & 33.5 \\
\hline \multicolumn{12}{|l|}{ Significance } \\
\hline Time & & NS & NS & NS & NS & NS & NS & NS & NS & NS & NS \\
\hline Concentration & & $\mathrm{L}^{* * * *}$ & $\mathrm{~L}^{* * *} \mathrm{Q}^{*}$ & NS & $\mathrm{L}^{* * *}$ & $\mathrm{~L}^{* * *}$ & $\mathrm{~L}^{* * *}$ & $\mathrm{~L}^{*}$ & $\mathrm{~L}^{* * *}$ & $\mathrm{~L}^{* * *} \mathrm{Q}^{*}$ & $\mathrm{~L}^{* * * *}$ \\
\hline Time $\times$ concentrati & & NS & NS & NS & NS & NS & NS & NS & NS & NS & NS \\
\hline
\end{tabular}

Ns, ***,* Nonsignificant or significant at $P=0.001$ or 0.05 , respectively. L and $\mathrm{Q}$ indicate a linear or quadratic response, respectively. 
Bukovac, M.J., J. Hull Jr., J.C. Neilson, M. Schroeder, and G. Noga. 1998. Interaction between CPPU and NAA on fruit thinning and fruit development in selected apple varieties. HortScience $33: 513$.

Curry, E.A. and D.W. Greene. 1993. CPPU influences fruit quality, fruit set, return bloom, and preharvest drop of apples. HortScience 28:115119.

Elfving, D.C. and R.A. Cline. 1993. Cytokinin and ethephon affect crop load, shoot growth, and nutrient concentration of 'Empire' apple trees. HortScience 28:1011-1014.

Fellman, C.D., P.E. Read, and M.A. Hosier. 1987. Effects of thidiazuron and CPPU on meristem formation and shoot proliferation. HortScience 22:1197-1200.

Forshey, C.G. 1986. Chemical thinning of apples. New York Food and Life Sci. Bul.\#116, Cornell Univ., Ithaca, N.Y.

Greene, D.W. 1989. CPPU influences 'McIntosh' apple crop load and fruit characteristics. HortScience 24:94-96.

Greene, D.W. 1993a. A comparison of the effects of several cytokinins on apple fruit set and fruit quality. Acta Hort. 329:144-146.

Greene, D.W. 1993b. A review of the use of benzyladenine (BA) as a chemical thinner for apples. Acta Hort. 329:231-236.

Greene, D.W. 1995. Thidiazuron effects on fruit set, fruit quality, and return bloom of apples. HortScience 30:1238-1240.

Greene, D.W. 1996. Influence of CPPU on fruit quality and storage potential of 'McIntosh' apples. J. Tree Fruit Prod. 1:87-97.

Looney, N.E. 1993. Improving fruit size, appearance, and other aspects of fruit crop 'quality' with plant bioregulant chemicals. Acta Hort. 329:120-127.

Mok, M.O., W.S. Mok, J.E. Turner, and C.V. Mujer. 1987. Biological and biochemical effects of cytokinin-active phenylurea derivatives in tis- sue culture systems. HortScience 22:1194-1197.

Priest, K.L. and E.C. Lougheed. 1981. Evaluating apple maturity using the starch- iodine test. Ontario Ministry of Agr. and Food Factsheet $81-025$.

Sugiyama, N., S Sansavini, D. Neri, and S. Tartarini. 1993. Effect of CPPU on fruit and shoot growth of apple. J. Hort Sci. 68:673-677.

Tartarini, S, S. Sansavini, and M. Ventura. 1993. CPPU control of fruit morphogenesis in apple. Scientia Hort. 54:273-279.

Weis, S.A., W.J. Bramlage, and M. Drake. 1985. Comparison of four sampling methods for predicting poststorage senescent breakdown of 'McIntosh' apple form from preharvest mineral composition. J. Amer. Soc. Hort. Sci. 110:710714.

Wismer, P.T., J.T. A. Proctor, and D.C. Elfving. 1995. Benzyladenine affects cell division and cell size during apple fruit thinning. J. Amer. Soc. Hort. Sci. 120:802-807. 